\title{
Application Research of Gravel and Machine-Made Sand along the KKH-2 Project in Pakistan on Asphalt Pavement
}

\author{
Jun Hu1,2, Xiao Tian ${ }^{3}$, Gang Wang3 ${ }^{3}$ Zhiqiang Wang ${ }^{3}$ \\ ${ }^{1}$ College of Water Conservancy and Architecture, Shihezi University, Shihezi, China \\ ${ }^{2}$ School of Civil Engineering and Mechanics, Huazhong University of Science and Technology, Wuhan, China \\ ${ }^{3}$ Overseas Branch of China Communications Road and Bridge Construction Co., Ltd., Beijing, China \\ Email:312110633@qq.com
}

How to cite this paper: $\mathrm{Hu}, \mathrm{J}$., Tian, $\mathrm{X}$., Wang, G. and Wang, Z.Q. (2019) Application Research of Gravel and Machine-Made Sand along the KKH-2 Project in Pakistan on Asphalt Pavement. World Journal of Engineering and Technology, 7, 622-633. https://doi.org/10.4236/wjet.2019.74045

Received: October 15, 2019

Accepted: November 4, 2019

Published: November 7, 2019

Copyright $\odot 2019$ by author(s) and Scientific Research Publishing Inc. This work is licensed under the Creative Commons Attribution International License (CC BY 4.0).

http://creativecommons.org/licenses/by/4.0/

\begin{abstract}
According to the characteristics of stone along the KKH-2 project in Pakistan, the applicability of gravel and machine-made sand for road engineering was studied. Through investigation, the types of stone along the project were relatively simple, and the stone materials used for road construction were mainly limestone, sandstone and pebbles, and the reserves were abundant. The experiment research and analyses comparisons of the parameters and road performance characteristics of natural gravel materials were carried out, and the design parameters and road performance indicators of natural grit in the current code were supplemented and adjusted to make it more suitable for Pakistan to use natural gravel materials for road construction. Thesis combines the project, proposing that mechanism sand and natural sand mixed concrete is not inferior to natural sand mixed concrete in terms of technical performance, and the overall cost is lower than that of natural sand mixed concrete. The research results are of great significance for saving engineering construction costs, ensuring road performance and prolonging service life.
\end{abstract}

\section{Keywords}

Pakistan KKH-2 Project, Stone along the Line, Machine-Made Sand Concrete, Experimental Research

\section{Preface}

This paper is based on the Pakistan KKH-2 Takot-Heveriyang Highway Project, which belongs to the Highway between the Haveli and Thakot sections of the China-Pakistan Economic Corridor, via Abbottabad, Mansehra and Hinkiari. 
The project area is $860-1880 \mathrm{~m}$ above sea level. The starting line mileage is K60 $+898.876-\mathrm{K} 80+318,(\mathrm{ZK} 80+330)($ except for ZK73 + $317-\mathrm{ZK} 75+030$ and $\mathrm{K} 73+280-\mathrm{K} 75+015$ tunnels), with a total length of $19.419 \mathrm{~km}$. According to preliminary investigations, the types of stone along the project are relatively single. The stone materials that can be used for road construction are mainly limestone, sandstone and pebbles, and the reserves are abundant. Since the choice of road construction materials is directly related to the performance and economy of the road, in order to rationally select local road construction materials, it is necessary to carry out the application research in-depth of the gravel and machine-made sand along the line of the KKH-2 phase Tarcote-Heverly Yang road in the asphalt. The application research in the mixture solves the applicability of the gravel and machine-made sand materials along the line for the sub-layers of the asphalt pavement surface, as well as the deficiencies of production process and quality control of the gravel and machine-made sand materials. It provides technical support for the use of gravel and machine-made sand materials in the construction of the special-Heverly Yang highway project, and provides reference for other engineering construction projects.

Therefore, under the premise of meeting the design and use requirements, the application research of gravel and machine-made sand along the KKH-2 Tacote-Heverly Yang road in the asphalt pavement surface layer is carried out, following the principle of "depending on local conditions, local materials, convenient construction, and cost savings", which is of great significance for ensuring project quality and saving construction costs.

The research content of this paper has certain practical significance for the comprehensive implementation of the road construction principle of "adapting to local conditions and local materials", and comprehensively promoting the construction of Pakistan's road network, and especially it has important reference value for Pakistan pavement structure design, engineering construction, maintenance and application of natural gravel, and it is of great significance for effectively utilizing Pakistan's natural gravel material resources, reducing construction cost and promoting environmental protection.

The results of the US SHRP program show that the angularity of the fine aggregate significantly affects the VV, VMA, water stability and shear strength of the asphalt mixture [1]. Anthony D. Staston et al. [2] believed that the angularity of fine aggregates had a great influence on the compaction of the pavement during the rolling stage, but had little effect on the compaction of the pavement during the operation period. Breakah [3] and Bausano [4] studied the influence of fine aggregate angularity on the design life of asphalt pavement. When using the same lithological fine aggregate, the angularity is good, and the pavement design life is long. Otherwise, the pavement design life is short. In addition, they also studied the correlation between angularity and stability, and the results showed that the correlation was good. Moore and Welke et al. [5] are consistent with and Breakah and Bausano, and believes that stability and angularity are better correlated. In addition, Han Haifeng and Lv Weimin [6] of Tongji Uni- 
versity have shown that the machine-made sand angularity has an important impact on the water stability of asphalt pavement.

\section{The Usage Situation of Machine-Made Sand}

The project site is extremely rich in sand and gravel materials [7]. Natural sand gravel materials have long been used as the base layer for secondary and below roads and the base layer for all grades of roads [8]. In recent years, with the rapid development of the economy, higher requirements have been placed on road capacity and pavement performance. In Pakistan, not only high-grade roads, but also many secondary roads have gradually adopted cement-stabilized gravel as the base layer, and the natural gravel that has been used for decades has gradually been eliminated as the secondary road pavement [9] [10] [11]. Although the semi-rigid base layer has many advantages, it also has problems such as easy cracking and high cost, and is it necessary to use a semi-rigid base layer for the secondary road? How much load can the graded gravel be used as the base of the pavement? Can we not use it in the secondary road? In order to solve these problems, the research project systematically studies and analyzes the parameters and road performance characteristics of natural gravel materials, and supplements and adjusts the design parameters and road performance indicators of natural grit in the current regulations to make it more suitable for Pakistan's need to build roads with natural gravel materials.

\section{Experimental Research Process}

\subsection{Concrete Preparation Target}

1) The mixture has good workability, large fluidity, cohesiveness, water retention, self-tightness and other properties. Under the premise of ensuring the quality, the slump value is designed to a maximum value of $230 \mathrm{~mm}$ to prevent the temperature of the mixture from being high and the slump loss is too large and the concrete pseudo-condensation phenomenon occurs under high temperature and long-distance pumping conditions. It can also reduce unfavorable factors such as excessive mixing error caused by uneven water content of the material.

2) Considering the unfavorable factors such as mixing error and the effect of low temperature in winter to reduce the strength of concrete, the natural strength of the prepared concrete specimens must be greater than $90 \%$ for 3 days to meet the construction needs of prestressed concrete, and reduce the concrete creep variables to ensure the tensile quality. The 28-day compressive strength of the formulated C30 concrete is not less than $30 \mathrm{MPa}$.

3) The retardation time of the prepared mixture meets the construction requirements, and the concrete pouring is $16-18$ hours according to the pouring amount and the production capacity of the mixing station. The retarding time should not be too long, which will affect the early strength growth of concrete; it should not be too short, because it will affect the quality of concrete. 
4) Select retarding high-efficiency water reducing agent and admixture to improve various properties of concrete, reduce hydration heat, and delay the release rate of hydration heat. The concrete mix ratio design meets the requirements of the design specifications of the anti-seepage concrete mix ratio and improves the crack resistance of the concrete.

5) Under the premise of ensuring the good working degree of the concrete mixture, the water-to-binder ratio can be reduced as much as possible to improve the strength of the concrete, reduce the shrinkage of the concrete, and reinforce the durability of the concrete.

6) The concrete elastic modulus Eh is not less than $3.0 \times 10^{4} \mathrm{MPa}$.

\subsection{Trial Raw Materials}

According to the above objectives, combined with the C30 grade concrete mix ratio test in the construction site test room, the Best Way low alkali cement with a strength grade of 42.5 is used, and all indicators meet the requirements of $\mathrm{Pa}$ kistan standards; high quality class II fly ash produced by Tacote Power Plant, Pakistan; S95 grade mineral powder produced in Pakistan, each indicator meets the requirements; The machine-made sand is the coarse sand of Zone I from the Tarcott Stone Field, with a fineness modulus of 3.4 and a stone powder content of $13 \%$; The coarse aggregate is a $5-31.5 \mathrm{~mm}$ continuous graded gravel in the Tarcott stone field; The admixture is selected from polycarboxylate superplasticizer produced in Pakistan; Use clean groundwater for mixing water. Some of the material pictures are as follows: (Figures 1-4).

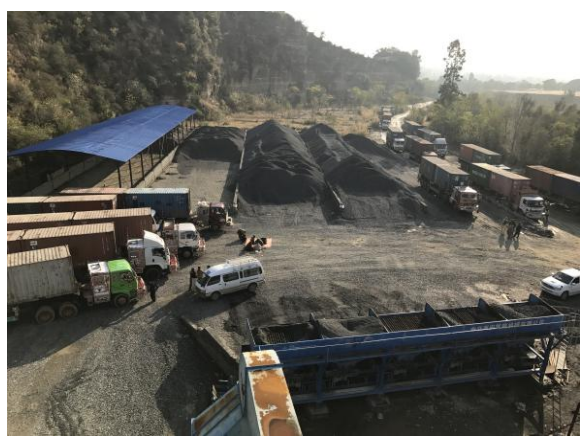

Figure 1. Machine-made sand.

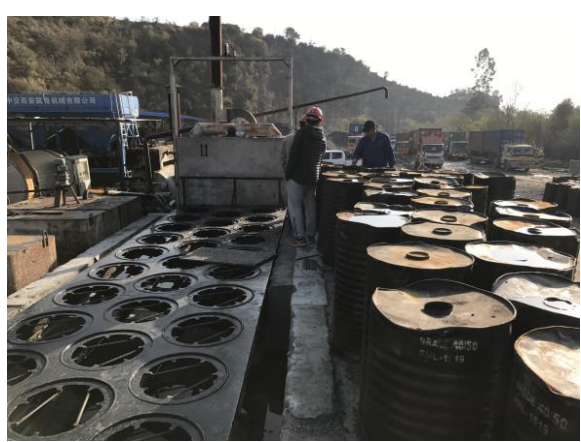

Figure 2. Asphalt. 


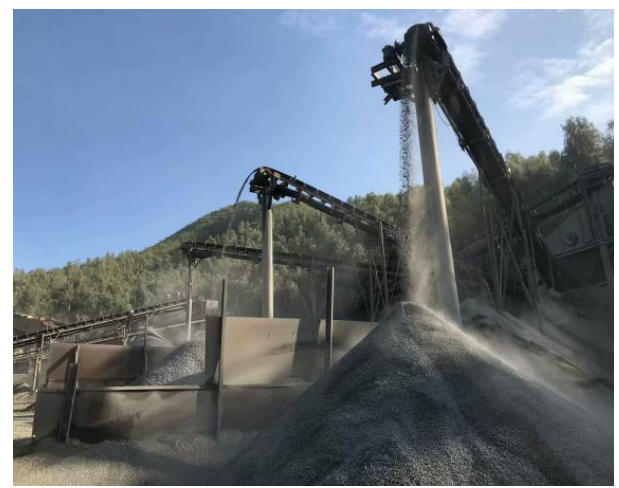

Figure 3. Machine-made sand processing.

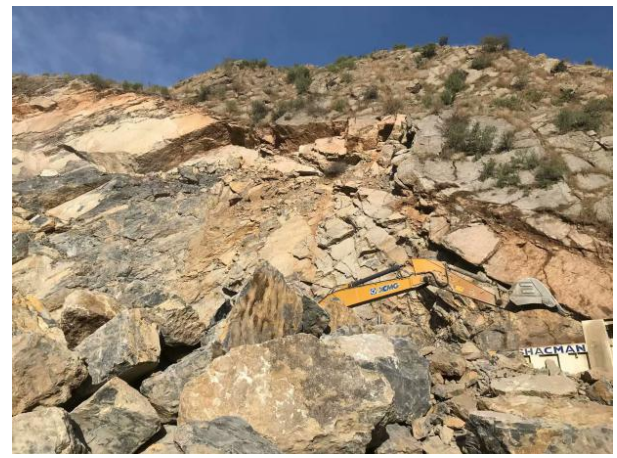

Figure 4. Gravel collection along the project.

\subsection{Preliminary Determination of C 30 Grade Concrete Mix Ratio}

According to the C30 grade concrete reference mix ratio by the laboratory early stage test and machine-made sand replaced in proportion, five ideal C30 grade concretes was initially determined, as shown in Table 1.

The compressive strength of each age of each mix concrete was compared by the following test: (Table 2).

The test results show that the optimum replacement rate of the concrete performance of each mix ratio is selected to determine the most economical mix ratio.

It can be seen from the test results that when the substitution rate of the machine-made sand is between $30 \%$ and $50 \%$, the working performance of the concrete is basically the same, but the substitution rate is relatively good at $30 \%$. The main reason is that the machine-made sand particles have more angular edges and the surface is rougher than natural sand. With the increase of the amount of machine-made sand, the frequency of the machine-made sand surface contact with each other increases, which affects the fluidity of the concrete.

The following is an attempt to replace the natural sand with $50 \%$ high stone powder sand to prepare C20 to C50 pumped concrete to see if it can meet the working performance, pouring performance and strength.

Then try to apply to the C20 to C50 grades of concrete, and compare the corresponding work performance and compressive strength (Table 3 and Table 4). 
Table 1. C30 pumping concrete different mechanism sand substitution rate test ratio.

\begin{tabular}{|c|c|c|c|c|c|c|c|c|}
\hline \multirow{2}{*}{$\begin{array}{c}\text { Test } \\
\text { number }\end{array}$} & \multirow{2}{*}{$\begin{array}{c}\text { Design } \\
\text { strength } \\
\text { level }\end{array}$} & \multirow{2}{*}{$\begin{array}{c}\text { Cementitious } \\
\text { material } \\
\left(\mathrm{kg} / \mathrm{m}^{3}\right)\end{array}$} & \multicolumn{2}{|c|}{ Fine aggregate $\left(\mathrm{kg} / \mathrm{m}^{3}\right)$} & \multirow{2}{*}{$\begin{array}{l}\text { Machine-made sand } \\
\text { substitution rate (\%) }\end{array}$} & \multirow{2}{*}{$\begin{array}{c}\text { Coarse } \\
\text { aggregate } \\
\left(\mathrm{kg} / \mathrm{m}^{3}\right)\end{array}$} & \multirow{2}{*}{$\begin{array}{l}\text { Water } \\
\left(\mathrm{kg} / \mathrm{m}^{3}\right)\end{array}$} & \multirow{2}{*}{$\begin{array}{l}\text { Water reducing } \\
\text { agent dosage (\%) }\end{array}$} \\
\hline & & & Natural sand & Machine-made sand & & & & \\
\hline 01 & $\mathrm{C} 30$ & 335 & 527.5 & 227.5 & 30 & 1120 & 160 & 2.0 \\
\hline 02 & $\mathrm{C} 30$ & 335 & 453 & 302 & 40 & 1120 & 160 & 2.0 \\
\hline 03 & $\mathrm{C} 30$ & 335 & 377.5 & 377.5 & 50 & 1120 & 160 & 2.05 \\
\hline 04 & $\mathrm{C} 30$ & 302 & 302 & 453 & 60 & 1120 & 160 & 2.05 \\
\hline 05 & C30 & 335 & 755 & 0 & 0 & 1120 & 160 & 2.05 \\
\hline
\end{tabular}

Table 2. Test results of different machine-made sand substitution rate of C30 pumped concrete.

\begin{tabular}{|c|c|c|c|c|c|c|}
\hline \multirow{2}{*}{$\begin{array}{c}\text { Test } \\
\text { number }\end{array}$} & \multirow{2}{*}{$\begin{array}{c}\text { Design } \\
\text { strength level }\end{array}$} & \multirow{2}{*}{$\begin{array}{l}\text { Workability } \\
\text { description }\end{array}$} & \multirow{2}{*}{ Slump (mm) } & \multicolumn{3}{|c|}{ Compressive strength (MPa) } \\
\hline & & & & 3 days & 7 days & 28 days \\
\hline 01 & C30 & $\begin{array}{l}\text { Good workability and } \\
\text { better cohesiveness }\end{array}$ & 180 & 16.3 & 27.6 & 36.7 \\
\hline 02 & $\mathrm{C} 30$ & Generality & 165 & 13.1 & 25.7 & 32.7 \\
\hline 03 & $\mathrm{C} 30$ & Generality & 160 & 13.0 & 25.4 & 32.5 \\
\hline 04 & $\mathrm{C} 30$ & Generality & 160 & 12.2 & 24.1 & 32.2 \\
\hline 05 & $\mathrm{C} 30$ & $\begin{array}{l}\text { Good workability and } \\
\text { good cohesiveness }\end{array}$ & 180 & 12.9 & 26.3 & 33.7 \\
\hline
\end{tabular}

Table 3. C20 - C50 pumping concrete 50\% machine-made sand substitution rate test ratio.

\begin{tabular}{|c|c|c|c|c|c|c|c|c|}
\hline \multirow{2}{*}{$\begin{array}{c}\text { Test } \\
\text { number }\end{array}$} & \multirow{2}{*}{$\begin{array}{c}\text { Design } \\
\text { strength } \\
\text { level }\end{array}$} & \multirow{2}{*}{$\begin{array}{c}\text { Cementitious } \\
\text { material }\left(\mathrm{kg} / \mathrm{m}^{3}\right)\end{array}$} & \multicolumn{2}{|c|}{ Fine aggregate $\left(\mathrm{kg} / \mathrm{m}^{3}\right)$} & \multirow{2}{*}{$\begin{array}{c}\text { Machine-made } \\
\text { sand substitution } \\
\text { rate }(\%)\end{array}$} & \multirow{2}{*}{$\begin{array}{c}\text { Coarse } \\
\text { aggregate } \\
\left(\mathrm{kg} / \mathrm{m}^{3}\right)\end{array}$} & \multirow{2}{*}{$\begin{array}{l}\text { Water } \\
\left(\mathrm{kg} / \mathrm{m}^{3}\right)\end{array}$} & \multirow{2}{*}{$\begin{array}{l}\text { Water reducing } \\
\text { agent dosage }(\%)\end{array}$} \\
\hline & & & Natural sand & Machine-made sand & & & & \\
\hline 06 & $\mathrm{C} 30$ & 335 & 755 & 0 & 0 & 1120 & 160 & 1.95 \\
\hline 07 & $\mathrm{C} 20$ & 275 & 397.5 & 397.5 & 50 & 1120 & 170 & 1.85 \\
\hline 08 & $\mathrm{C} 25$ & 305 & 387.5 & 387.5 & 50 & 1120 & 165 & 1.90 \\
\hline 09 & $\mathrm{C} 30$ & 335 & 377.5 & 377.5 & 50 & 1120 & 160 & 1.95 \\
\hline 10 & $\mathrm{C} 35$ & 365 & 367.5 & 367.5 & 50 & 1120 & 155 & 2.1 \\
\hline 11 & $\mathrm{C} 40$ & 395 & 357.5 & 357.5 & 50 & 1120 & 150 & 2.4 \\
\hline 12 & $\mathrm{C} 45$ & 430 & 342.5 & 342.5 & 50 & 1120 & 150 & 2.5 \\
\hline 13 & C50 & 470 & 325 & 325 & 50 & 1120 & 150 & 2.7 \\
\hline
\end{tabular}

The results showed that:

When the high stone powder content machine-made sand replaces $50 \%$ of the natural sand, in order to make the working performance of the concrete meet the requirements, it is necessary to increase the dosage of the admixture, especially the high-grade concrete. Thus, the cost advantage of using machine-made sand for concrete is compromised and can also cause other problems.

Therefore, the next step is to pass the high-silver content of the machine-made sand through a $0.630 \mathrm{~mm}$ sieve, sieve the stone powder and fine 
Table 4. Test results of 50\% machine-made sand substitution rate of C20 - C50 pumped concrete.

\begin{tabular}{|c|c|c|c|c|c|c|}
\hline \multirow{2}{*}{$\begin{array}{c}\text { Test } \\
\text { number }\end{array}$} & \multirow{2}{*}{$\begin{array}{c}\text { Design } \\
\text { strength } \\
\text { level }\end{array}$} & \multirow{2}{*}{ Workability description } & \multirow{2}{*}{$\begin{array}{l}\text { Slump } \\
(\mathrm{mm})\end{array}$} & \multicolumn{3}{|c|}{$\begin{array}{l}\text { Compressive strength } \\
\qquad(\mathrm{MPa})\end{array}$} \\
\hline & & & & 3 days & 7 days & 28 days \\
\hline 06 & C30 & $\begin{array}{l}\text { Good workability, } \\
\text { slight bleeding }\end{array}$ & 195 & 14.7 & 24.4 & 34.7 \\
\hline 07 & $\mathrm{C} 20$ & $\begin{array}{l}\text { Good workability, no bleeding, } \\
\text { good cohesiveness }\end{array}$ & 190 & 8.5 & 15.8 & 22.9 \\
\hline 08 & $\mathrm{C} 25$ & $\begin{array}{l}\text { Good workability, no bleeding, } \\
\text { good cohesiveness }\end{array}$ & 180 & 10.3 & 18.5 & 27.1 \\
\hline 09 & C30 & $\begin{array}{c}\text { Good workability, } \\
\text { no bleeding, good cohesiveness }\end{array}$ & 180 & 12.8 & 22.0 & 30.9 \\
\hline 10 & C35 & $\begin{array}{c}\text { Good workability, } \\
\text { no bleeding, good cohesiveness }\end{array}$ & 185 & 15.6 & 26.4 & 34.7 \\
\hline 11 & C40 & $\begin{array}{c}\text { Good workability, } \\
\text { no bleeding, good cohesiveness }\end{array}$ & 195 & 18.3 & 30.9 & 39.6 \\
\hline 12 & C45 & $\begin{array}{c}\text { Good workability, } \\
\text { no bleeding, good cohesiveness }\end{array}$ & 185 & 23.4 & 36.5 & 45.0 \\
\hline 13 & C50 & $\begin{array}{c}\text { Good workability, } \\
\text { no bleeding, good cohesiveness }\end{array}$ & 200 & 26.7 & 40.6 & 47.5 \\
\hline
\end{tabular}

particles and then test it to see if the amount of admixture can be reduced after the stone powder is reduced, meanwhile the replacement rate is also $50 \%$ natural sand (Table 5 and Table 6).

The results showed that:

The high stone powder content factor has a certain influence on the factors affecting the working performance of the concrete prepared by replacing the natural sand with the high sand powder content machine-made sand. However, the mixed concrete work performance issues can be better solved by improving or increasing the amount of the water reducing agent.

Next, the natural sand was replaced by $30 \%$ and $50 \%$ substitution rate for medium and low-grade pumping concrete, and the corresponding work performance and compressive strength were compared (Table 7 and Table 8).

The results showed that:

For medium and low-grade pumping concrete, the mixed concrete workability is better when we replace $30 \%$ natural sand with machine-made sand, and the concrete with $50 \%$ substitution rate is relatively poor. Even if the dosage of admixture is increased, it is still impossible to solve the problem of poor compatibility.

The following experiment was conducted with the use of machine-made sand at $50 \%$ and $100 \%$ replacement rate for ordinary pavement concrete and low slump concrete (Table 9 and Table 10). 
Table 5. Machine-made sand substitution rate test after 50\% sifting of C20 - C50 pumped concrete.

\begin{tabular}{|c|c|c|c|c|c|c|c|c|}
\hline \multirow{2}{*}{$\begin{array}{c}\text { Test } \\
\text { number }\end{array}$} & \multirow{2}{*}{$\begin{array}{c}\text { Design } \\
\text { strength } \\
\text { level }\end{array}$} & \multirow{2}{*}{$\begin{array}{c}\text { Cementitious } \\
\text { material }\left(\mathrm{kg} / \mathrm{m}^{3}\right)\end{array}$} & \multicolumn{2}{|c|}{ Fine aggregate $\left(\mathrm{kg} / \mathrm{m}^{3}\right)$} & \multirow{2}{*}{$\begin{array}{l}\text { Machine-made sand } \\
\text { substitution rate (\%) }\end{array}$} & \multirow{2}{*}{$\begin{array}{c}\text { Coarse } \\
\text { aggregate } \\
\left(\mathrm{kg} / \mathrm{m}^{3}\right)\end{array}$} & \multirow{2}{*}{$\begin{array}{l}\text { Water } \\
\left(\mathrm{kg} / \mathrm{m}^{3}\right)\end{array}$} & \multirow{2}{*}{$\begin{array}{c}\text { Water } \\
\text { reducing agen } \\
\text { dosage }(\%)\end{array}$} \\
\hline & & & Natural sand & Machine-made sand & & & & \\
\hline 14 & $\mathrm{C} 30$ & 335 & 755 & 0 & 0 & 1120 & 160 & 1.95 \\
\hline 15 & $\mathrm{C} 30$ & 335 & 377.5 & 377.5 & 50 & 1120 & 160 & 2.23 \\
\hline 16 & $\mathrm{C} 35$ & 365 & 367.5 & 367.5 & 50 & 1120 & 155 & 2.20 \\
\hline 17 & $\mathrm{C} 40$ & 395 & 357.5 & 357.5 & 50 & 1120 & 150 & 2.25 \\
\hline 18 & $\mathrm{C} 45$ & 430 & 342.5 & 342.5 & 50 & 1120 & 150 & 2.50 \\
\hline 19 & $\mathrm{C} 50$ & 470 & 325 & 325 & 50 & 1120 & 150 & 2.53 \\
\hline
\end{tabular}

Table 6. Test results of machine-made sand substitution rate after 50\% sifting of C20 - C50 pumped concrete.

\begin{tabular}{|c|c|c|c|c|c|c|}
\hline \multirow{2}{*}{$\begin{array}{c}\text { Test } \\
\text { number }\end{array}$} & \multirow{2}{*}{$\begin{array}{c}\text { Design } \\
\text { strength level }\end{array}$} & \multirow{2}{*}{ Workability description } & \multirow{2}{*}{$\begin{array}{l}\text { Slump } \\
(\mathrm{mm})\end{array}$} & \multicolumn{3}{|c|}{ Compressive strength (MPa) } \\
\hline & & & & 3 days & 7 days & 28 days \\
\hline 14 & $\mathrm{C} 30$ & Good workability and good cohesiveness & 180 & - & 22.5 & 32.5 \\
\hline 15 & $\mathrm{C} 30$ & Generality & 170 & - & 21.3 & 32.6 \\
\hline 16 & $\mathrm{C} 35$ & Generality & 170 & - & 24.0 & 32.9 \\
\hline 17 & $\mathrm{C} 40$ & Generality & 160 & - & 30.5 & 40.4 \\
\hline 18 & $\mathrm{C} 45$ & Generality & 160 & - & 30.0 & 44.8 \\
\hline 19 & C50 & Good workability and good cohesiveness & 185 & - & 37.4 & 52.6 \\
\hline
\end{tabular}

Table 7. Comparison of sand substitution rate test rates for different machine-made sand of low-grade pumping concrete.

\begin{tabular}{|c|c|c|c|c|c|c|c|c|}
\hline \multirow{2}{*}{$\begin{array}{c}\text { Test } \\
\text { number }\end{array}$} & \multirow{2}{*}{$\begin{array}{c}\text { Design } \\
\text { strength level }\end{array}$} & \multirow{2}{*}{$\begin{array}{c}\text { Cementitious } \\
\text { material }\left(\mathrm{kg} / \mathrm{m}^{3}\right)\end{array}$} & \multicolumn{2}{|c|}{ Fine aggregate $\left(\mathrm{kg} / \mathrm{m}^{3}\right)$} & \multirow{2}{*}{$\begin{array}{l}\text { Machine-made } \\
\text { sand substitution } \\
\text { rate (\%) }\end{array}$} & \multirow{2}{*}{$\begin{array}{c}\text { Coarse } \\
\text { aggregate } \\
\left(\mathrm{kg} / \mathrm{m}^{3}\right)\end{array}$} & \multirow{2}{*}{$\begin{array}{l}\text { Water } \\
\left(\mathrm{kg} / \mathrm{m}^{3}\right)\end{array}$} & \multirow{2}{*}{$\begin{array}{l}\text { Water reducing } \\
\text { agent dosage } \\
(\%)\end{array}$} \\
\hline & & & $\begin{array}{l}\text { Natural } \\
\text { sand }\end{array}$ & $\begin{array}{l}\text { Machine-made } \\
\text { sand }\end{array}$ & & & & \\
\hline 20 & $\mathrm{C} 25$ & 305 & 775 & 0 & 0 & 1120 & 165 & 1.75 \\
\hline 21 & $\mathrm{C} 20$ & 275 & 556.5 & 238.5 & 30 & 1120 & 170 & 1.95 \\
\hline 22 & $\mathrm{C} 20$ & 275 & 397.5 & 397.5 & 50 & 1120 & 170 & 2.2 \\
\hline 23 & $\mathrm{C} 25$ & 305 & 542.5 & 232.5 & 30 & 1120 & 165 & 2.0 \\
\hline 24 & $\mathrm{C} 25$ & 305 & 387.5 & 387.5 & 50 & 1120 & 165 & 2.0 \\
\hline 25 & $\mathrm{C} 30$ & 335 & 528.5 & 226.5 & 30 & 1120 & 160 & 2.1 \\
\hline 26 & $\mathrm{C} 30$ & 335 & 377.5 & 377.5 & 50 & 1120 & 160 & 2.4 \\
\hline
\end{tabular}

Table 8. Test results of sand substitution rate of different machine-made for low-grade pumping concrete.

\begin{tabular}{ccccccc}
\hline \multirow{2}{*}{$\begin{array}{c}\text { Test } \\
\text { number }\end{array}$} & $\begin{array}{c}\text { Design } \\
\text { strength level }\end{array}$ & Workability description & $\begin{array}{c}\text { Slump } \\
(\mathrm{mm})\end{array}$ & \multicolumn{3}{c}{ Compressive strength (MPa) } \\
\cline { 5 - 7 } 20 & C25 & Good workability, good cohesiveness & 185 & 3 days & 7 days & 28 days \\
21 & C20 & Good workability, good cohesiveness & 190 & 14.9 & 24.3 \\
22 & C20 & Poor workability & 140 & 7.7 & 11.5 & 19.6 \\
23 & C25 & Good workability & 170 & 9.0 & 13.8 & 23.3 \\
24 & C25 & Poor workability & 145 & 8.9 & 14.2 & 23.3 \\
25 & C30 & Good workability & 175 & 11.6 & 18.3 & 28.6 \\
26 & C30 & Poor workability & 145 & 11.7 & 17.2 & 28.6 \\
\hline
\end{tabular}


Table 9. Machine-made mixed sand test ratio of ordinary pavement concrete and low slump concrete.

\begin{tabular}{|c|c|c|c|c|c|c|c|c|}
\hline \multirow{2}{*}{$\begin{array}{c}\text { Test } \\
\text { number }\end{array}$} & \multirow{2}{*}{$\begin{array}{l}\text { Design } \\
\text { strength } \\
\text { level }\end{array}$} & \multirow{2}{*}{$\begin{array}{c}\text { Cementitious } \\
\text { material }\left(\mathrm{kg} / \mathrm{m}^{3}\right)\end{array}$} & \multicolumn{2}{|c|}{ Fine aggregate $\left(\mathrm{kg} / \mathrm{m}^{3}\right)$} & \multirow{2}{*}{$\begin{array}{l}\text { Machine-made } \\
\text { sand substitution } \\
\text { rate }(\%)\end{array}$} & \multirow{2}{*}{$\begin{array}{l}\text { Coarse } \\
\text { aggregate } \\
\left(\mathrm{kg} / \mathrm{m}^{3}\right)\end{array}$} & \multirow{2}{*}{$\begin{array}{l}\text { Water } \\
\left(\mathrm{kg} / \mathrm{m}^{3}\right)\end{array}$} & \multirow{2}{*}{$\begin{array}{l}\text { Water reducing } \\
\text { agent dosage (\%) }\end{array}$} \\
\hline & & & $\begin{array}{l}\text { Natural } \\
\text { sand }\end{array}$ & $\begin{array}{l}\text { Machine-made } \\
\text { sand }\end{array}$ & & & & \\
\hline 27 & $\mathrm{C} 25$ & 310 & 750 & 0 & 0 & 1160 & 150 & 1.75 \\
\hline 28 & $\mathrm{C} 25$ & 310 & 375 & 375 & 50 & 1160 & 150 & 1.75 \\
\hline 29 & $\mathrm{C} 25$ & 310 & 0 & 750 & 100 & 1160 & 150 & 1.75 \\
\hline 30 & $\mathrm{C} 45$ & 440 & 325 & 325 & 50 & 1160 & 140 & 2.0 \\
\hline 31 & C45 & 440 & 0 & 650 & 100 & 1160 & 140 & 2.0 \\
\hline 32 & $\mathrm{C} 25$ & 300 & 680 & 0 & 0 & 1240 & 160 & 1.35 \\
\hline 33 & $\mathrm{C} 25$ & 300 & 340 & 340 & 50 & 1240 & 160 & 1.35 \\
\hline 34 & $\mathrm{C} 25$ & 300 & 0 & 680 & 100 & 1240 & 160 & 1.35 \\
\hline
\end{tabular}

Table 10. Machine-made mixed sand test results of ordinary pavement concrete and low slump concrete.

\begin{tabular}{|c|c|c|c|c|c|c|}
\hline \multirow{2}{*}{$\begin{array}{c}\text { Test } \\
\text { number }\end{array}$} & \multirow{2}{*}{$\begin{array}{c}\text { Design } \\
\text { strength level }\end{array}$} & \multirow{2}{*}{$\begin{array}{l}\text { Workability } \\
\text { description }\end{array}$} & \multirow{2}{*}{$\begin{array}{l}\text { Slump } \\
(\mathrm{mm})\end{array}$} & \multicolumn{3}{|c|}{ Compressive strength (MPa) } \\
\hline & & & & 3 days & 7 days & 28 days \\
\hline 27 & $\mathrm{C} 25$ & Good workability, good cohesiveness & 155 & 12.1 & 18.9 & 28.8 \\
\hline 28 & $\mathrm{C} 25$ & Good workability, good cohesiveness & 120 & 12.1 & 18.0 & 31.2 \\
\hline 29 & $\mathrm{C} 25$ & Generality & 90 & 12.0 & 17.1 & 28.3 \\
\hline 30 & $\mathrm{C} 45$ & Average fluidity and good cohesiveness & 130 & 25.2 & 33.5 & 44.1 \\
\hline 31 & $\mathrm{C} 45$ & Poor workability, knotting, bottoming & 80 & 26.1 & 33.6 & 45.0 \\
\hline 32 & $\mathrm{C} 25$ & Good workability, poor cohesiveness & 150 & 16.2 & 19.7 & 27.0 \\
\hline 33 & $\mathrm{C} 25$ & Good workability, good cohesiveness & 130 & 18.0 & 21.7 & 28.1 \\
\hline 34 & $\mathrm{C} 25$ & Good workability & 110 & 16.7 & 20.9 & 24.8 \\
\hline
\end{tabular}

\subsection{Analysis and Experience of Test Results}

1) The machine-made sand produced in the process of crushed stone production has high content of sandstone powder, poor particle size distribution, and high stone powder content can only be used to prepare concrete less than C30 grade. If the concrete is mixed with machine-made sand natural sand in a ratio of 3:7, the pumped concrete of less than C40 grade can be well prepared.

2) Replace the natural sand with $30 \%$ high stone powder content machine-made sand to prepare pumped concrete. The mechanical properties of the powder are slightly better than pure natural sand due to the filling effect of the stone powder. It is effective to replace natural sand with $50 \%$ machine-made sand to prepare ordinary pavement concrete and low slump concrete, and it is not necessary to significantly increase the dosage of admixture, and the economic benefit is obvious.

3) Using high stone powder content machine-made sand to replace part of natural sand to prepare concrete can not only save natural resources, but also save costs and have significant economic benefits. 
4) In combination with the actual situation in the region, the high stone powder content machine-made sand needs to be properly treated before use to better ensure the quality stability of the machine-made sand.

5) From the experimental research and experience accumulation, determine the optimal cooperation of mixed sand concrete and pure natural sand concrete, such as the following Table 11.

\section{Cost Analysis}

Although the amount of admixture used in the pumping concrete which use mixed sand is improved, the mixed sand is cheaper than the pure natural sand, especially in the low slump concrete and the pavement concrete machine-made sand have a higher substitution rate, and the admixture dosage is basically the same, and the cost advantage is more obvious. The medium and low level pumping concrete can save 3 yuan, and the ordinary road surface and low slump non-pumping concrete can save more than 6 yuan, and the comprehensive economic benefits are obvious (Table 12).

Table 11. Mixing ratio of mixed sand concrete and pure natural sand concrete.

\begin{tabular}{|c|c|c|c|c|c|c|c|c|c|c|c|}
\hline \multirow{2}{*}{$\begin{array}{l}\text { Serial } \\
\text { number }\end{array}$} & \multirow{2}{*}{$\begin{array}{c}\text { Power } \\
\text { level }\end{array}$} & \multirow{2}{*}{$\begin{array}{l}\text { Concrete } \\
\text { type }\end{array}$} & \multicolumn{9}{|c|}{ Concrete prepared ratio $\left(\mathrm{kg} / \mathrm{m}^{3}\right)$} \\
\hline & & & Cement & $\begin{array}{c}\text { Slag } \\
\text { powder }\end{array}$ & $\begin{array}{l}\text { Fly } \\
\text { ash }\end{array}$ & $\begin{array}{l}\text { Natural } \\
\text { sand }\end{array}$ & $\begin{array}{l}\text { Machine-made } \\
\text { sand }\end{array}$ & Guamite & $\begin{array}{c}1-3 \\
\text { stone }\end{array}$ & Water & $\begin{array}{c}\text { Admixture } \\
\text { dosage }\end{array}$ \\
\hline 01 & $\mathrm{C} 30$ & Ordinary pumping class & 170 & 60 & 105 & 755 & 0 & 280 & 840 & 160 & 1.90 \\
\hline 02 & $\mathrm{C} 30$ & Ordinary pumping class & 170 & 60 & 105 & 528.5 & 226.5 & 280 & 840 & 160 & 2.10 \\
\hline 03 & $\mathrm{C} 20$ & Ordinary pumping class & 130 & 50 & 95 & 795 & 0 & 280 & 840 & 170 & 1.80 \\
\hline 04 & $\mathrm{C} 20$ & Ordinary pumping class & 130 & 50 & 95 & 556.5 & 238.5 & 280 & 840 & 170 & 1.95 \\
\hline 05 & $\mathrm{C} 25$ & Ordinary pumping class & 155 & 55 & 100 & 775 & 0 & 280 & 840 & 165 & 1.85 \\
\hline 06 & $\mathrm{C} 25$ & Ordinary pumping class & 155 & 55 & 100 & 542.5 & 232.5 & 280 & 840 & 165 & 2.00 \\
\hline 07 & $\mathrm{C} 30$ & $\begin{array}{c}\text { Low slump } \\
\text { non-pumping class }\end{array}$ & 185 & 50 & 75 & 750 & 0 & 150 & 1010 & 150 & 1.75 \\
\hline 08 & $\mathrm{C} 30$ & $\begin{array}{c}\text { Low slump } \\
\text { non-pumping class }\end{array}$ & 185 & 50 & 75 & 375 & 375 & 150 & 1010 & 150 & 1.85 \\
\hline 09 & $\mathrm{C} 30$ & Ordinary pavement & 250 & 0 & 60 & 680 & 0 & 0 & 1230 & 160 & 1.35 \\
\hline 10 & $\mathrm{C} 30$ & Ordinary pavement & 250 & 0 & 60 & 340 & 340 & 0 & 1230 & 160 & 1.45 \\
\hline
\end{tabular}

Table 12. Concrete cost analysis.

\begin{tabular}{cccc}
\hline \multirow{2}{*}{$\begin{array}{c}\text { Concrete } \\
\text { grade }\end{array}$} & Concrete type & Sand saving cost & Cost (yuan $\left./ \mathrm{m}^{3}\right)$ \\
\cline { 3 - 4 } C30 & Ordinary pumping class & $(226.5 \times 20) / 1000=4.53$ & $335 \times 2 \times 0.2 \%=1.34$ \\
Increased cost of water reducer & 3.19 \\
C20 & Ordinary pumping class & $(238.5 \times 20) / 1000=4.77$ & $275 \times 2 \times 0.15 \%=0.83$ \\
C25 & Ordinary pumping class & $(232.5 \times 20) / 1000=4.65$ & $305 \times 2 \times 0.15 \%=0.92$ \\
C30 & Low slump non-pumping class & $(375 \times 20) / 1000=7.5$ & $310 \times 2 \times 0.1 \%=0.62$ \\
C30 & Ordinary pavement & $(340 \times 20) / 1000=6.8$ & $310 \times 2 \times 0.1 \%=0.62$ \\
\hline
\end{tabular}


In the above table, the price difference per cubic meter of the machine-made sand and the pure natural sand is calculated as 30 yuan/ton; The water reducing agent is calculated at a price difference of about RMB 20/ton.

\section{Conclusions}

1) The machine-made sand produced in the process of crushed stone production has high content of sandstone powder and poor particle-level matching. If the machine-made sand is mixed with natural sand in a ratio of 3:7, the pumped concrete of less than C40 grade can be well prepared.

2) If machine-made sand mixes with natural sand in a ratio of 1:1, the effect of preparing ordinary pavement concrete and low slump concrete is good, and the dosage of admixture is not obviously increased, and the economic benefit is obvious.

3) Using high stone powder content machine-made sand to replace part of natural sand to prepare concrete can not only save natural resources, but also save costs and have significant economic benefits.

4) In combination with the actual situation of the KKH-2 project in Pakistan, the high stone powder content machine-made sand needs to be properly treated before use to better ensure the quality stability of the machine-made sand.

\section{Conflicts of Interest}

The authors declare no conflicts of interest regarding the publication of this paper.

\section{References}

[1] SHRP-A-415 (1994) Permanent Deformation Response of Asphalt Aggregate Mixes. N.C.R, USA.

[2] Stakston, A.D., Bahia, H.U. and Bushek, J.J. (2002) Effect of Fine Aggregate Angularity on Compaction and Shearing Resistance of Asphalt Mixtures. Transportation Research Record: Journal of the Transportation Research Board, 1789, 14-24. https://doi.org/10.3141/1789-02

[3] Breakah, T.M. and Williams, R.C. (2013) Dynamic Testing of Hot Mix Asphalt for Moisture Susceptibility Assessment. Construction and Building Materials, 47, 636-642. https://doi.org/10.1016/j.conbuildmat.2013.05.014

[4] Bausano, J., Post, N.L., Case, S.W. and Lesko, J.J. (2006) Modeling the Remaining Strength of Structural Composite Materials Subjected to Fatigue. International Journal of Fatigue, 28, 1100-1108. https://doi.org/10.1016/j.ijfatigue.2006.02.016

[5] Moore, J. and Welke, J.E. (2014) Effect of the Physical Properties of Aggregates on Aggregate-Asphalt Bond Measured Using the UCL Method. Construction and Building Materials, 73, 399-406. https://doi.org/10.1016/j.conbuildmat.2014.09.098

[6] Han, H.F. and Lu, W.M. (2002) Effect of Fine Aggregate Angularity on Performance of Asphalt Mixture. Journal of Tongji University, 30, 302-306.

[7] Jiang, L.H. (2006) Concrete Materials Science. Hohai University Press, Shanghai.

[8] He, Z.F. (2009) Experimental Study on the Application of Tailings in Ready-Mixed Concrete. Commercial Concrete, 6, 42-46. 
[9] Liu, Z.H. (2018) Application of Machine-Made Sand in Asphalt Pavement Structure Layer. Highway Transportation Technology, 6, 6-7.

[10] Li, T.T. (2009) Application Research of Mechanism Sand in Jicha Expressway. Master Thesis of Wuhan University of Technology, Wuhan, 5.

[11] Fang, S.W. (2015) Adaptability of Mechanism Sand in Asphalt Mixture. Master's Thesis of Chang'an University, Chang'an, 6. 